\title{
Ten years of bliss: the scientific ABCs of unite and conquer
}

\author{
Sylvia Daunert
}

Published online: 1 December 2011

(C) Springer-Verlag 2011

The last decade has brought us many social, political, and economic challenges and changes. The world is not the same now as when the first idea was born to create a journal, Analytical and Bioanalytical Chemistry a.k.a. ABC, to address the need for dissemination of cutting-edge analytical, biological and environmental research in partnership with European chemical societies. In the past ten years the world has been stricken by a series of both natural and man-caused disasters: the South-East Asian tsunami, the Japanese earthquake and nuclear spill, the China and Chile earthquakes, hurricane Katrina, just to name a few; in addition to genocides and civil wars in Africa, and the worst terrorist attack in history on September 11, 2001. These are tragedies that marked our lives, created a new fear of natural catastrophic events, and made us aware of the danger posed by fanatics and their disregard for human life. Two horrendous wars in Afghanistan and Iraq resulted not only in grief and sorrow for humankind, but also in a significant economic impact on Western nations, unavoidably coaffecting our research enterprises. In the United States of America, it was the beginning of a shift from funds devoted to research to war-related expenses, which materialized in serious cuts in resources for the US agencies that typically support academic and governmental research. Industrial research suffered perhaps even more. The collapse of Wall Street put the economy of the United States into a downward

S. Daunert $(\square)$

Department of Biochemistry and Molecular Biology, R. Bunn Gautier Bldg., Miller School of Medicine, University of Miami, 1011 NW 15th Street,

Miami, FL 33136, USA

e-mail: SDaunert@med.miami.edu

e-mail: DaunertEdit@med.miami.edu spiral that is proving to be hard to recover from. As companies adjusted to the new economic reality, they made choices that were more product-oriented than research and innovation-centered. This decrease and, in some cases, termination of investments by the private sector in discovery and development of future technologies, is compromising the edge that the United States had as leaders in innovation, a dangerous position to be in when looking into the future. Although in the beginning the economic crisis was not as pronounced within the European Union, the global disastrous economy ended up trickling down to Europe also. Research programs in Europe also suffered, and countries, for example Spain, where investment in research in the late 20th and early 21 st centuries had led to an unparalleled increase in scientific discovery and creation of state-of-the-art technology, were affected. There is no doubt that this economic debacle has caused a great deal of damage to progress in global science and technology, but the lack of funds also created a need for being more imaginative on how we approach finding resources and conducting scientific research. In science, as in politics, there have been many divide-and-conquer tactics, which do not work to promote progressive solutions in the long term [1]. Rather, advances in science depend on unity, alignment, and partnership.

A more concerted effort, or a "unite and conquer" approach, as I like to describe it, has emerged, whether voluntarily or out of need. This has been evident on many different fronts. A need has been created by a changing world which has seen the rise of countries such as China, India, and Brazil, for example, and developments such as the Arab spring. The pressing need for resourcefulness in terms of stretching the available funds to the maximum has resulted in successful strategies for many investigators and research institutions. Some of these efforts are contained within a 
single institution, whereas others are either nation-wide or global. Perhaps the most common effort in that regard is related to teams of investigators from different fields coming together to tackle complex research problems that just one group could never conquer because of its limited expertise and, in some instances, the limitations of its funds to perform such costly work across disciplines. Examples of multidisciplinary teams of scientists and engineers coming together to solve problems can be found within academia, industry and government laboratories. Institutional teams are the most prevalent, and are now present in almost every academic research university in Europe, Asia, and North America. Moreover, this approach has led to the creation of consortia between academic, industrial, and governmental institutions in individual countries and across nations. A few top biomedical and pharmaceutical companies have established worldwide research institutes to promote collaboration among scientists in academia and industry. The spectacular discoveries and technologies stemming from some of these collaborations have already led to benefits to humankind. In 2001, the then European Union, EU, Research Chief, Philippe Busquin, proposed a "unite and conquer" strategy to advance research programs within the countries of the EU [2]. This strategy has been very successful, and resulted in the creation of consortia and common grants and fellowships for students to cross-pollinate the European research enterprise. Canada, Australia, the United States, China, and the European Union also provided the initial funding for the creation of the International Human Microbiome Consortium [3], which now has grown to foster a wide array of research programs in the founding countries and in others. A large number of European scientists and pharmaceutical partners are working jointly as part of the Innovative Medicines Initiative (IMI), the largest public-private initiative in Europe, the objective of which is to speed the development of better and safer drugs to cure target diseases [4]. This initiative, which is the result of a joint venture between the European Union and the European Pharmaceutical Industry Association, EFPIA, sponsors collaborative research projects, an example being the OncoTrack aimed at discovering novel genomic diagnostics for cancer [5]. The IMI also creates networks of industrial and academic scientists to foster discovery science and innovation in Europe. The overcome attitude of secrecy and reluctance to share scientific information and discoveries had in some instances resulted in delayed progress and duplication of efforts, with subsequent loss of time and misuse of monetary and human resources. Efforts like those described above are a step forward in surmounting these obstacles.

The impending problems that our world faces have created the need to form teams. An interesting outcome from the realization that the lack of food, clean water, and healthcare available to people in developing countries will have devastating effects, has attracted unprecedented global inter- est. Indeed, a few private foundations, for example the Bill and Melinda Gates Foundation [6], have intervened to fund creative solutions to global problems. The Gates Foundation is, for example, funding projects by scientists throughout the world to develop new diagnostics for widespread diseases such as malaria and tuberculosis, and new vaccines and delivery systems for infectious diseases. Defeating the hunger and dietary malnutrition of millions of people in Africa and South Asia, because of insufficient availability of nutritious foods, remains a serious challenge. Increased morbidity and mortality worldwide can be attributed to dietary micronutrient deficiencies, e.g., lack of vitamin A, iodine, iron, or zinc. These deficiencies can be overcome by ingestion of a varied diet, rich in vegetables, fruit, and animal products. However, poor developing countries with harsh climates and little water have neither the natural resources nor the economic power to provide their inhabitants with these diets. The objective of the "Golden Rice Project" is to prepare genetically engineered rice crops rich in $\beta$-carotenes (vitamin A precursors) and to distribute the technology to the developing countries [7]. This is a pioneering effort in which academia, governments, and the public sector have come together to explore the introduction of nutrient-enriched genetically modified staple foods into the diets of malnourished populations. While the use of genetically modified foods, GMOs, has many detractors, who believe that these non-naturally occurring foods are harmful, in the last ten years important milestones, for example production of these crops in open fields, have been reached and make their widespread use an attainable reality. To gain more support, it is necessary to increase the public's trust in GMOs by careful analytical demonstration of their safety and efficacy. The potential effect of this technology in reducing the morbidity and mortality of large populations in developing countries is extraordinary and, thus, from a humanitarian point of view, demonstrating unequivocally GMOs' safety should be a priority of the scientific community.

The energy crisis, ever-increasing pollution with the consequent destruction of the environment, and the reality of climate change have spurred a worldwide effort and the creation of a myriad of organizations and consortia across the public and private sectors whose objective is to address and find solutions to these problems. In 2011, the United States and China announced the creation of three US-China Clean Energy Research Center consortia focusing on cooperation in building efficiency, advanced coal and carbon-capture and storage, and clean vehicles [8]. These two countries also agreed to start joint programs to develop the next generation of aviation biofuels and to draft guidelines and policies to support the integration of energy efficiency and renewable energy into city design and operation [8]. Given that China and the United States are the largest contributors of greenhouse gas emissions to our planet, joint efforts at 
addressing environmental issues are of critical importance. Another important milestone related to energy as a result of a "unite and conquer" approach came was passed when, in February of 2011, the European Council, held its first energy meeting at which heads of state and government agreed that safe, sustainable, and affordable energy contributes to Europe's competitiveness, and is a priority for the EU [9]. Indeed, the President of the European Commission, José Manuel Barroso, not only stressed the need for a serious commitment to energy and innovation as related to the priorities of the Commission's Energy 2020 Program and Energy Infrastructure Communications, but also called for Europe to become the "natural home of innovation" in technology associated with energy [10]. The EU already funds multi-disciplinary teams of investigators across Europe to perform research in sustainable and green energy technology, biofuels, climate change, and environmental remediation. What is now needed is timely implementation of the developed technology, which calls for aggressive industrial partnerships.

Added benefits of the "unite and conquer" approach for the teams of investigators involved in problem solving include personal, cultural, and professional growth for each team member involved in the effort. With regard to educating the new generation of scientists, engineers, and physician scientists working in multi-disciplinary, multi-ethnic teams provide students with invaluable experience that prepares them to understand problems with a more global and realistic perspective. This new generation of researchers is poised to solve critical challenges because they are trained to approach these problems in a multi-dimensional manner. Let us not forget Leonardo da Vinci and his technological inventionsthe most creative solutions have come from a renaissance-type of science and engineering. Very much like him, the epitome of a scientist "wearing different hats", future generations of scientists will need to be versatile and able to think in both parallel and intersecting dimensions to come up with transforming discoveries. Yet, important discoveries may not have an impact unless there is a translation of the technology into a useful application. Translational science and technology are crucial to making the benefits of bench discovery a reality. In the last decade, scientists have made progress in translational science and realized its paramount importance. As Francis Collins, Director of the United States National Institutes of Health (NIH), stated in a recent commentary: "Despite dramatic advances in the molecular pathogenesis of disease, translation of basic biomedical research into safe and effective clinical applications remains a slow, expensive, and failure-prone endeavor" [11]. To address this problem and establish means of "disruptive translational innovation", the NIH has decided to create the National Center for Advancing Translational Sciences (NCATS). According to Collins "The mission of NCATS is to catalyze the generation of innovative methods and technologies that will enhance the development, testing, and implementation of diagnostics and therapeutics across a wide range of diseases and conditions." The intention is that the NCATS will complement translational research stemming from both the public and private sectors [11]. The creation of an entity such as NCATS is a step in the right direction in the promotion of the application of discovery to every day life. In a different manner, but in a similar fashion, Steve Jobs, Apple's recently deceased former Chief Executive Officer, led technology transformative milestones with his vision translating advances in electronic, communication and semiconductor technology into devices that have empowered millions of humans to use computers and communicate face-to-face with others across the globe. As a 21st century visionary, Jobs had an ingenious imagination that led to the creation of technology that transformed our world [12]. To advance science and technology to the next level, we need more individuals with his lateral thinking and the means of implementing their ideas. To that end, a trend at top Universities and innovative companies is not only to assemble teams of students or employees with diverse expertise to solve problems, but also to invest in innovation. Google, for example, a model company in terms of working environment and approach to hiring its workforce, has an arm, Google Ventures, whose mission is to invest in innovative technology [13]. Recognizing the need for investment in futuristic start-up companies, not just product-centric enterprises, is, in itself, a welcome shift in investment strategy that should propel non-traditional research ventures and ideas. We need more of these types of investment strategies to be able to deliver, in a timely fashion, technological advances to the public at the same pace as discovery, whether by academic, governmental or private institutions.

Finally, I should emphasize that our journal is a prime example of scientific "unite and conquer". Ten years ago, the German Chemical Society (Gesellschaft Deutscher Chemiker, GDCh), the French Chemical Society (Société Chimique de France, SFC), and the Spanish Society for Analytical Chemistry (Sociedad Española de Química Analítica, SEQA) joined forces with Springer to create the new journal ABC. The founding managing editor, Dr Christina Dyllick, approached me in late 2000 with the offer of becoming one of the editors of the new journal. At the time, I was pregnant with my third child, was running an ever growing well-funded research program, and leading several educational academic ventures at my institution and at the American Chemical Society, all of which contributed to a slight hesitation to join the effort. However, the concept of uniting all the individual analytical chemistry journals of the European societies into one, with the objective of consolidating the best European science and expanding it to the rest of the world in the form of a premier publication, won me over. Discovering who my 
fellow five founding editors were, Drs Phillipe Garrigues (France), Günter Gauglitz (Germany), Klaus Heumann (Germany), Kiyokatsu Jinno (Japan), and Stephen Wise (USA), all renowned in their own fields of chemistry, finally convinced me. Having the privilege of being involved in naming the journal "Analytical and Bioanalytical Chemistry" was, indeed, an added bonus! The mission of our journal is to communicate advances in state-of-the-art measurement science to the scientific community. From the journal's inception, Dr Dyllick, an innovative editor, encouraged the scientific editors not to be exclusive, but rather inclusive regarding the fields we chose to publish, as long as they emphasized measurement science. As a result, our journal has published papers focusing on environmental, clinical, biochemical, materials, energy, and analytical science, and even art and archeometric work. I am proud that $\mathrm{ABC}$ is open to publication of research that does not fit into just one category of science, but rather is at an intersection of disciplines, consequently encouraging and validating the importance of interdisciplinary research. The success of our journal has been quite spectacular. The Spanish Royal Chemical Society (Real Sociedad Española de Química, RSEQ), the Austrian Chemical Society (Österreichische Gesellschaft für Analytische Chemie, ASAC), the Division of Analytical Chemistry of the Swiss Chemical Society (DAC/SCS), the Italian Chemical Society (Società Chimica Italiana, SCI), and the Polish Chemical Society (Polskie Towarzystwo Chemiczne, PTChem) joined as co-owning societies and now eight supporting societies around the world have become our partners. The increasing editorial demands resulted in Drs Alfredo Sanz-Medel (Spain) and Aldo Roda (Italy) joining us as editors in 2003 and 2010, respectively. Moreover, two Regional Editors have joined the Editorial Board: Dr Maciej Jarosz for Central Europe and Dr Lihua Zhang for China.

Our impact factor continues to increase annually at the fastest rate of all analytical journals. In 2010, a change in managing leadership at Springer was necessary as a result of the retirement of our incomparable founding managing editor, Dr Christina Dyllick. The transition to a new team of managing editors at Springer in Heidelberg led by Dr Steffen Pauly and including Drs Andrea Pfeifer and Nicola Oberbeckmann-Winter has been seamless and resulted in further growth. In our current era of burgeoning scientific discovery and technology development, the need for rapid and accurate communication among scientists, physician scientists, and engineers is critical in furthering scientific advancement. In response to this demand, Analytical and Bioanalytical Chemistry will continue to serve the community of science and its evolving needs with the same dedication, efficiency, and avant-garde policy that has been in place since its inauguration in 2001. On behalf of me and my fellow editors, I would like to thank the managing, publishing, and production teams at Springer, the International Advisory
Board, and more importantly, our contributors and readers for their support in making Analytical and Bioanalytical Chemistry one of the top journals in measurement science.

All of us might wish at times that we lived in a more tranquil world, but we don't. And if our times are difficult and perplexing, so are they challenging and filled with opportunity.

Robert F. Kennedy (1925-1968)

\section{References}

1. Sinema K (2009) Unite and conquer: how to build coalitions that win and last. Berrett-Koehler Publishers, San Francisco, CA

2. Koenig R (2001) E.U. research chief's strategy: unite and conquer. Science 292:2425-24xx

3. The International Human Microbiome Consortium: http://www. human-microbiome.org/

4. The Innovative Medicines Initiative: http://www.imi.europa.eu/

5. OncoTrack: http://www.oncotrack.org/

6. The Bill and Melinda Gates Foundation: www.gatesfoundation.org/

7. The Golden Rice Project: http://www.goldenrice.org/index.html

8. Natural Resources Defense Council Staff Blog: http://switchboard. nrdc.org/blogs/bfinamore/president hu and president oba.html

9. European Commission: Energy: http://ec.europa.eu/energy/time to act en.htm

10. Conclusions on Energy, European Council, 4 February, 2011: http://www.consilium.europa.eu/uedocs/cms_Data/docs/pressdata/ en/ec/119141.pdf

11. Collins FS (2011) Reengineering translational science: the time is right. Science Translational Medicine 3:1-6

12. Markoff J (2011) Apple's visionary redefined digital age. The New York Times, October 5, 2011; also, for a timeline of inventions and products see: http://online.wsj.com/article/ SB10001424052702304447804576410753210811910.html\#project \%3DAPPLEJOBS0111\%26articleTabs\%3Dinteractive

13. Google Ventures: http://www.googleventures.com/how-we-canhelp.html

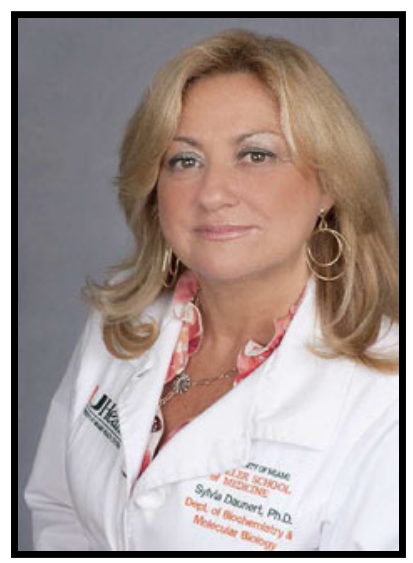

Sylvia Daunert holds the Lucille P. Markey Chair of Biochemistry and Molecular Biology at the Miller School of Medicine of the University of Miami. Previously, she was the Gill Eminent Professor of Chemistry at the University of Kentucky where she had a secondary appointment in the Pharmaceutical Sciences. Dr Daunert's research interests are in bionanotechnology at the interface between analytical biochemistry, molecular biology, and bioengineering. Her group uses recombinant DNA technology to design new molecular diagnostic tools and biosensors, based on genetically engineered proteins and cells, which have biomedical, environmental, and pharmaceutical applications. The research of the group also focuses on the design of sensing arrays for detection of molecules in small volumes, by use of microfluidics, and in the development of biomaterials for responsive drug-delivery systems. 